\title{
Development of Teaching Materials Based on a Metacognition Approach to Improve the Understanding Ability of Mathematical Concepts of Students of Budi Mulia Medan
}

\author{
Mahdalena Elma Sari, M. Amin Fauzi, Faiz Ahyaningsih* \\ Postgraduate Program in Mathematics Education, Medan State University, Indonesia \\ *Corresponding author: mahdalena.elmasari29@gmail.com
}

Received November 17, 2018; Revised December 28, 2018; Accepted January 08, 2019

\begin{abstract}
This study aims to: 1) Develop teaching materials based on a valid metacognition approach to improve students' understanding of mathematical concepts; 2) Developing teaching materials based on a practical metacognition approach to improve the ability to understand students' mathematical concepts; 3) Develop teaching materials based on an effective metacognition approach; 4) To analyze the increased ability to understand students' mathematical concepts by using teaching materials based on metacognition approaches. This research is a development research using a 4-D development model, the teaching materials developed from this study are: Learning Implementation Plans, Teacher Books, Student Books, Student Worksheets, And Tests Ability To Understand Mathematical Concepts. From the results of trial I and trial II, it was obtained: 1) Teaching materials based on the metacognition approach developed have met valid criteria from several criteria; 2) Teaching materials based on the metacognition approach developed have met Practical criteria from several criteria; 3) Teaching materials based on the metacognition approach developed have met the effective criteria of several criteria; 4) there is an increase in the ability to understand students' mathematical concepts by using instructional materials based on the metacognition approach developed, in the trial I obtained an average score of pretest $54.66 \%$ and posttest score $73.86 \%$, and in the second trial with an average pretest score of $57.87 \%$ and posttest score of $78.4 \%$.
\end{abstract}

Keywords: teaching material development, metacognition approach, 4-D model, ability to understand mathematical concepts

Cite This Article: Mahdalena Elma Sari, M. Amin Fauzi, and Faiz Ahyaningsih, "Development of Teaching Materials Based on a Metacognition Approach to Improve the Understanding Ability of Mathematical Concepts of Students of Budi Mulia Medan.” American Journal of Educational Research, vol. 7, no. 1 (2019): 24-32. doi: 10.12691/education-7-1-5.

\section{Introduction}

Understanding a concept well is very important for students, because in solving problems students must know the rules that are relevant and these rules are based on the concepts obtained. Understanding of understanding is expressed by Bloom (in Hadijah) [1] Understanding includes goals, behaviors, or responses that reflect something understanding of written messages contained in one communication. Therefore students are required to understand or understand what is being taught, to know what is being communicated and to be able to use its contents without having to connect with other things. Walle [2] states "understanding can be defined as a measure of the quality and quantity of an idea's relationship with an existing idea". The level of understanding varies, understanding depends on the idea that has been owned and depends on making new relationships between ideas.
Meanwhile, according to Gagne [3] states the concept is "an abstract idea that allows classifying objects into examples and non-examples".

Based on the explanation above, increasing the ability to understand mathematical concepts needs to be the focus of attention in mathematics learning. Now the emphasized learning is student-centered learning where students are given the opportunity to understand the problems faced until they get the right solution or conclusion, and the teacher is only a facilitator. In line with Hasibuan [4] "The error in delivering by the teacher is fatal to the students in facing the next problem that's still related to theconcept and at last causes a less-intention for the students to learn mathematics".

According to Duffin and Simpson (in Kesumawati) [5] understanding concepts as students' ability to: (1) explain concepts, can mean students are able to re-express what has been communicated to them, (2) use concepts in different situations, and (3) develop some consequences of a concept. 
But the reality is based on the ability to understand students' mathematical concepts on the initial observation in Budi Mulia Middle School. The test results of students' comprehension ability showed unfavorable results indicated by: (1) only 25\% (8 students) could rephrase a mathematical concept given by the teacher with his own language; (2) only 31.25\% (10 students) can provide examples and not examples in the book related to the concepts given by the teacher; (3) only $28.1 \%$ (9 students) can apply the mathematical concepts given by the teacher to solve the given questions. This condition clearly illustrates that the ability to understand students' mathematical concepts in mathematics learning must be continually improved/improved, considering that understanding the mathematical concepts of students that are good can make it easier for students to understand the material and solve the given problems.

Responding to problems that occur in the field, namely in the process of learning mathematics in schools, especially relating to the ability to understand mathematical concepts that result in low learning outcomes of mathematics, the teacher must make efforts to improve this condition. Efforts made include improving quality through the learning process. Teachers are required to describe mathematics learning activities in the form of teaching materials and learning implementation plans. According to Nur (in Sulistyaningsih) [6] stated "teaching materials provide convenience and can help teachers in preparing and carrying out teaching and learning activities in the classroom". So that the right teaching materials can make students easy to learn mathematics.

Many efforts can be made to achieve the objectives in learning, one of them is by developing teaching materials according to Ahmadi [7] "Teaching materials are all forms of materials used to assist teachers or instructors in carrying out teaching and learning activities in the classroom". In line with that according to Kusumam [8] "teachers are expected to be able to design or compile teaching materials that play a role in determining the success of the learning process and learning through the implementation of mathematics learning, often the teacher has difficulty in delivering the material so that students get the concept correctly".

In developing teaching materials it is necessary to pay attention to the quality of teaching materials developed. According to Nieveen [9]. "There are criteria in determining the quality of the results of the development of teaching materials, namely (1) validity (valid); (2) practivally (practical) and (3) effectiveness (effective). By developing valid, practical and effective teaching materials teachers can also evaluate the extent to which the success of the instructional materials developed can be applied well in the ongoing learning process in the classroom.

From the description above it can be seen that teaching material is one of the efforts to improve the quality of the teaching and learning process. But in fact in the field that there are still many teachers who have not designed teaching materials well. Based on observations and interviews conducted on teachers and students of Budi Mulia Medan Middle School on September 19, 2017. Textbooks used by teachers when teaching were only textbooks provided by the school so students were rarely given questions to train students' abilities because of the limitations of textbooks. which are owned.

The teaching material used has not honed the ability to understand students' mathematical concepts. The specifications only use book teaching materials, there are no Student Worksheets that support the ability to understand students' mathematical concepts. Students worksheet is one component that supports textbooks in teaching materials. According to Fahrie (in Fannie), [9] stated "Student worksheets are sheets that are used as guidelines in learning and contain tasks that must be done by students in certain studies". Therefore, besides textbooks, it is also needed in carrying out the learning process.

The development of important teaching materials is done by the teacher so that learning is more effective, efficient, and does not deviate from the competencies that will be achieved. Teaching materials developed should be teaching materials that can construct the ability to understand mathematical concepts in students. This is supported by Ramdani [10] who focuses on developing teaching materials aimed at increasing the ability to understand students' mathematical concepts. In line with the results of the study Lasmiyati \& Idris [11] suggested that the results of the analysis of the data after the treatment, it was concluded that mathematics teaching materials were effective in terms of understanding the concepts and interests of learning mathematics. This is because the developed teaching materials are designed to be interesting and use communicative and simple language, so that students can understand it.

The low ability to understand students' mathematical concepts is also caused by many other factors, including the orientation of education in Indonesia generally to treat students as objects, teachers as the highest scientific authority and subject-oriented material. Handayani, [12] suspects that teacher-centered learning results in passive students in classroom learning. Such education causes our educational practices to isolate themselves from real life outside of school, less relevant between what is taught with needs in work, too concentrated on intellectual development that does not work with individual development as a whole and personality.

In developing teaching materials that direct students to the ability to understand mathematical concepts, of course models, approaches and strategies must be chosen that are in line with the abilities students want to achieve. One way that can be used to improve the ability to understand mathematical concepts is the metacognition approach.

Hamzah (in Widianingsih) [13] revealed that the metacognition process is able to guide students play an active role in constructing their knowledge meaningfully, so that students' metacognition skills need to be used for the learning process and eventually students will be able to achieve maximum performance. The importance of metacognition knowledge is also expressed by Williams \& Atkins (in Rukminingrum) [14] which is helping students carry out many of their learning tasks more effectively. Metacognitive knowledge provides an important role in student learning activities so it is necessary to apply it. The metacognition approach used by students depends on internal factors such as values and motivation in students, their perception of task demands, and teaching the teacher. North Central Regional Education Laboratory (NCREL) 
(in yamin) [15] revealed that students who use the metacognition approach usually do the following: 1) actively seek information to expand their learning strategies, 2) match strategies with learning tasks, adjust when needed, 3) asking for instructions from peers or teachers, and 4) using study time according to their own thoughts.

Based on previous research, Mawaddah [16] stated that, there is a positive influence on the metacognition approach and process skills on students' mathematical creative thinking skills by 83 , and the teacher's observations in implementing an instrument that has an average of 4.45 with good criteria and questionnaire calculation results. response of students who have an average of 3.77 with good criteria. Furthermore, the research conducted by Widianingsih \& Wulan [17] suggested that the metacognition approach had a significant influence on increasing the ability to understand concepts, the effect was seen from the difference in mean values in the two dependent variables. This can be used as a consideration to use the metacognition approach as an alternative to the many forms of learning oriented / centered approaches students in improving mathematical abilities which are ultimately expected to improve student learning outcomes.

From the results of previous research described above, the metacognition approach can improve students' abilities because metacognition is a learning approach that emphasizes self-understanding of learning material, whether or not it understands the subject matter being studied, because metacognition is an understanding of what thought about one's understanding ability. Seeing the importance of the metacognition approach in enhancing the ability to understand mathematical concepts students must seek to develop teaching materials based on metacognition approaches. But in fact there is no teaching material developed by the teacher in Medan Budi Mulia Middle School using the metacognition approach

Based on the description above, the study that focuses on developing teaching materials is important to do. This study was entitled: "Development of Teaching Materials Based on Metacognition Approaches to Improve the Understanding Ability of Mathematical Concepts of students of students of Budi Mulia Medan".

\section{Research Methods}

This research is a development research with the 4-D Thiagarajan model, which consists of four stages: define, design, develop and disseminate.

\subsection{Subjects and Research Objects}

Subjects in this study were students of class VIII-A, VIII-B and VIII-C SMP Budi Mulia in the academic year $2017 / 2018$, each of which amounted to 25 people. While the object in this study was while the object in this study was the development of teaching-based materials metacognition approach on cube and beam material namely Learning Implementation Plan, Teacher's Guidebook, Student Book, Student Worksheet, Mathematical Concept Understanding Ability Test (TKPKM).

\subsection{Procedures for Developing Teaching Materials}

This research is classified into four stages, namely: define, design phase, develop and disseminate through a trial.

\subsection{Data Analysis and Instruments}

The instrument used in this study is an instrument to measure the validity and effectiveness of the learning tools developed, namely validation sheets, tests and questionnaires.

\subsubsection{Learning Material Validity}

Teaching materials are validated to experts namely five validators by giving scores 1 to 5 in each column of assessment based on aspects: (1) format, (2) language, (3) content, and (4) illustration. Furthermore expert judgment as a whole is processed by calculating the average score to get the validity criteria if Va or Average Total Value $1 \leq \mathrm{Va}<2$ Validity Criteria Not valid, $2 \leq \mathrm{Va}$ $<3$ Less valid, $3 \leq \mathrm{Va}<4$ Fairly valid, $4 \leq \mathrm{Va}<5$ Valid and $\mathrm{Va}=5$ Very valid

Information:

Va: The value of determining the validity level of teaching materials based on a metacognition approach

Teaching materials based on metacognition approach meet the expected validity if the average validator assessment of all learning devices is valid or very valid. If it has not been reached, it needs to be validated again until valid. Furthermore, the test instrument for the ability to understand mathematical concepts of students was tested outside the sample class to measure the validity and reliability of the instrument. The validity of the item is calculated using the Sugiono Product Moment correlation formula [18]

The reliability coefficient of the problem was calculated using the Alpha Arikunto formula [19].

\subsubsection{Quality of Teaching Materials}

Nieveen [20] suggested several criteria used to obtain quality teaching materials, namely (1) validity (validity), (2) practicality (practically), and (3) effectiveness (effectiveness). In line with Rochmad [20] "the results of research development in the field of education conducted by students and generally produce a prototype model or teaching material that is valid, practical, and effective".

\subsubsection{Increased Ability to Understand Students' Mathematical Concepts}

The magnitude of the increase in the ability to understand students' mathematical concepts is calculated by the N-gain formula of Hake [21] as follows:

$$
N-\text { gain }=\frac{\text { skor postest }- \text { skor pretest }}{\text { skor ideal }- \text { skor pretest }}
$$

With the gain index criteria $g \geq 0,7$ in the High category, $0,3 \leq g<0,7$ with Medium and $g<0,3$ in the Low category. 


\section{Research Result}

\subsection{Description of the Stages of Teaching Material Development}

\subsubsection{The Results of the Development of Teaching Materials Using Thiagarajan $\neg 4$-D Models are Described as Follows}

To produce these objectives, first research on the development of using the 4-D Model from Thiagarajan, Semmel and Semmel was described including the stages of define, design, develop, and disseminate. Data analysis and research results are presented as follows:

\section{Define}

Based on observations on teaching materials in Medan Budi Mulia Middle School Based on the analysis of students' answers to the tests given during observation, students were not able to distinguish between examples and not examples, and there were some students who were unable solving a problem correctly students are only able to identify problems without a solution. This requires the teacher to choose an appropriate strategy or approach to improve the ability to understand mathematical concepts has not developed a lesson plan according to the characteristics of students, subject matter in the book used by teachers and students does not lead students to the ability to understand concepts, and students do not use LAS to support learning activities. Furthermore, in the learning process the teacher still uses conventional approaches.

\section{Design}

At this stage, several things are produced and they are lesson plans for 4 meetings, Teacher's Guide book, Student's Books, Student Worksheets, mathematical concept comprehension tests, alternative solutions, scoring guidelines, and all of the results at this design stage are called draft $I$.

\section{Develop}

At this stage, validation of draft I was carried out to the experts and then field trials were also carried out. The aim is to see the weakness in draft I so that revisions and improvements to the teaching materials developed can be made. The results of expert validation in the form of assessment of content validity shows that all teaching materials meet valid criteria, with the total average value of Learning Implementation Plan validation is 4.53, Student Worksheets is 4.41, Teacher Manual is 4.43, and Student Books is 4.43. All test items ability to understand students' mathematical concepts meet valid and reliable criteria. Instrument reliability is used to determine the test results. After calculating, the reliability of the ability to understand mathematical concepts is obtained by 0.815 (very high category).

After the developed teaching materials have fulfilled the validity criteria, then the teaching materials in draft II are tested in the research place in Budi Mulia Medan Junior High School, which is hereinafter referred to as the first test. Developed result has not met all the effective criteria, so improvements are made to produce teaching materials that meet all the effective criteria set. Revisions were made based on the findings of the learning device weaknesses in the first trial, namely for related to the allocation of learning time, as well as on Student Books and Student Worksheets related to the material being taught. After the revision is complete, trial II is conducted to determine the effectiveness of teaching materials, as well as increasing the ability to understand students' mathematical concepts.

\section{Disseminate}

This stage is the final stage in the 4-D development model. The results of this stage are to recommend to the mathematics subject teachers, especially the VIII class of field trial schools to use this teaching material as an alternative learning method for cubes and beams.

\subsection{Trial Results I}

\subsubsection{Quality of Teaching Materials in Trial I}

The first trial was conducted to see the consistency of teaching materials developed based on metacognition approaches, which aimed to improve the ability to understand students' mathematical concepts. In the field trial I was conducted to measure the practicality and effectiveness of teaching materials (draft II) developed based on a metacognition approach aimed at improve the ability to understand students' mathematical concepts.

\subsubsection{Results of Practical Teaching Materials in Test I}

Teaching materials based on the developed metacognition approach are said to be practical in terms of (1) expert / practitioner assessment of the developed teaching materials can be used with little revision or without revision; (2) teachers and students state that the instructional material developed can be used easily, and (3) the results of observing the implementation of teaching materials in the class are included in the minimum high category $(3 \leq P<4)$.

a. Description of Expert / Practitioner Assessment of

\section{Teaching Materials}

Based on the mastery of the theory and experience, experts and practitioners state that teaching materials based on the metacognition approach can be used with little revision.

\section{b. Description of the response of students and teachers to the use of teaching materials}

From the interview results above it can be seen that students' responses to the developed teaching materials are very positive, students feel the ease of using them. In addition students like the form of presentation of material and the problems given. Especially for worksheets, students like the questions given, namely metacognition questions. This shows that students consider teaching materials to be used practically.

From the interview results above it can be seen that the teacher's response to the developed teaching material is very positive, the teacher feels the ease in using it. Even the teacher was happy and very interested in the teacher's instruction book because it was equipped with instructions for the teacher in the implementation and there was a trajectory hypothetical learning which was very helpful for the teacher and made the teacher not forget to emphasize the important parts for students in finding a concept. This shows that the teacher considers teaching materials to be used practically. 


\section{c. Description of Implementation of \\ Trial Teaching Materials I}

The implementation of teaching materials based on the metacognition approach is measured by using the instructional implementation observation sheet based on the metacognition approach. The results of the analysis of observational data on the implementation of teaching materials based on the metacognition approach concluded that the achievement of the level of implementation of teaching materials in the trial I was included in the high category, which meant that teaching materials based on metacognition approach were said to be practical or applicable. The average value of observing the feasibility of teaching materials for each meeting in trial $\mathrm{I}$ is shown in Figure 1.

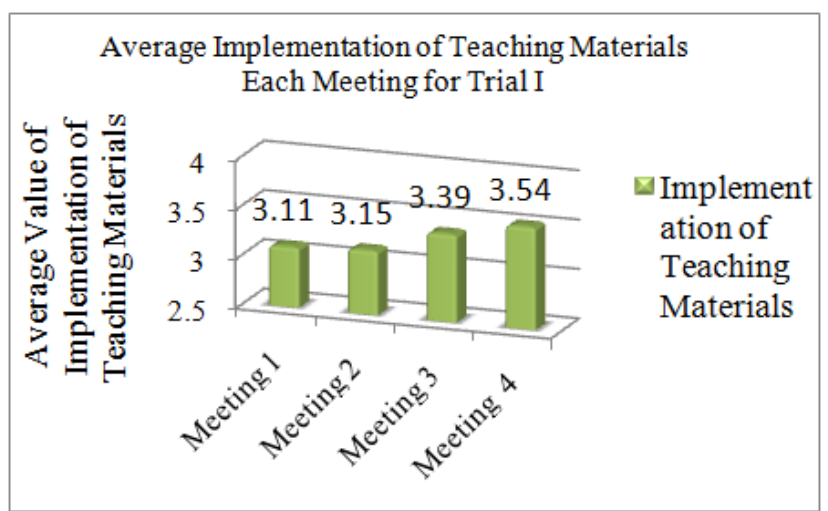

Figure 1. Average implementation of teaching materials in Test I for each meeting

It is seen that the average at the four meetings meets the criteria for the implementation of high-grade teaching materials. This certainly has an impact on the overall implementation of instructional materials for the three meetings in the first trial I have an average of 3.30. For more details can be seen in the diagram presented in Figure 2 below:

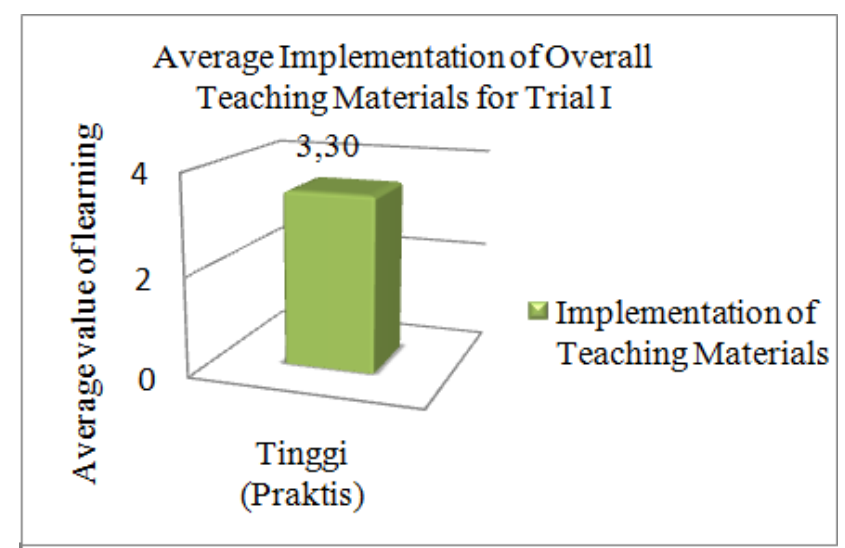

Figure 2. Average Implementation of Overall Teaching Materials for Trial I

The average value of the implementation of the overall teaching material in the first trial is 3.30 if referred to the criteria for the implementation of teaching materials in Chapter III, the value is in the high category with a minimum ranges $3 \leq \bar{P}<4$. Thus it can be concluded that, teaching materials based on the metacognition approach developed are practical in terms of the implementation of teaching materials.

\subsubsection{Description of the Effectiveness of Teaching Materials in Trial I}

\section{a. Classical Student Learning Completeness Trial I}

From the results of the analysis of the trial data I found that the instructional material developed was not effective, because there were still some indicators of effectiveness that had not been achieved. In the first trial, the percentage of classical completeness achieved has not met the criteria for achieving classical completeness shown in Figure 3 below:

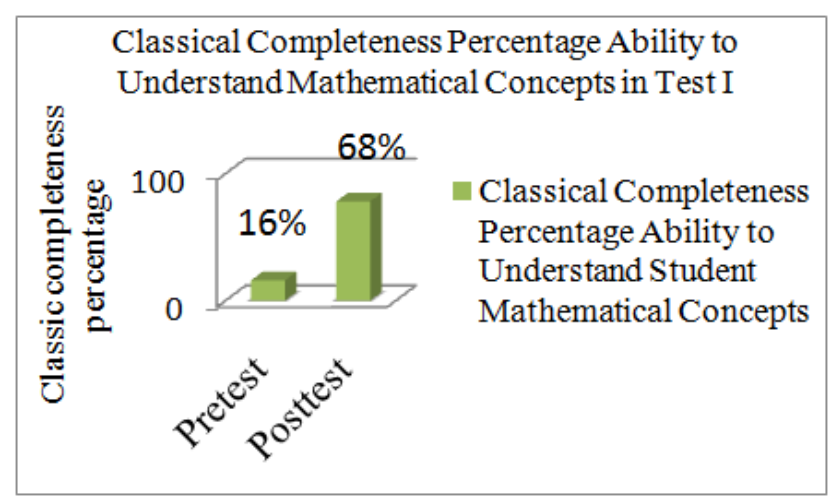

Figure 3 Classical Completeness Percentage Ability to Understand Mathematical Concepts in Test I

Based on the picture above shows that the classical completeness of the results of the ability to understand students' mathematical concepts at pretest trial I was $16 \%$ while in the posttest trial I was $68 \%$. In accordance with the criteria of classical student learning completeness, which is at least $85 \%$ of students who take part in learning are able to achieve a minimum score of 70 , then the posttest results in the ability to understand mathematical concepts in test I have not met the criteria for achieving classical completeness because they only obtained $68 \%$ completeness.

If categorized based on the level of mastery of students, then the level of mastery of students' ability to understand mathematical concepts on the results of pretest and posttest trial I can be seen in Figure 4.

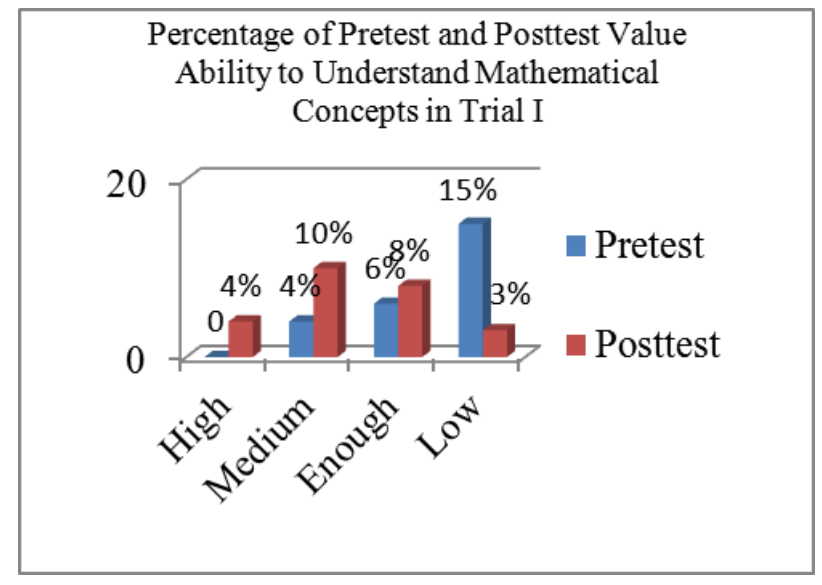

Figure 4. Percentage of Pretest Value and Posttest Understanding of Mathematical Concept Ability in Trial I 
Data obtained from the results of the pretest and posttest ability to understand students 'mathematical concepts in the first trial were analyzed to determine the ability to understand students' mathematical concepts. The improvement is seen by calculating the value of n-Gain based on the results of the pretest and posttest in trial I.

The results of N-Gain students if viewed based on the average pretest and posttest scores the ability to understand mathematical concepts also increased. The average pretest and posttest in trial I were 58.74 and 70.15, respectively, which resulted in a difference between pretest and posttest values of 11.41. Based on the results of the N-Gain calculation, it was found that increasing the ability to understand students' mathematical concepts in the first trial was 0.29 or categorized as "Low". Thus the use of teaching materials based on the metacognition approach developed has not been able to improve the ability to understand students' mathematical concepts in trial I.

\section{b. Achievement of the Development Goals in Trial I}

Furthermore, for the criteria for achieving the learning objectives in the first trial I have not yet reached each item.

Table 1. Achievement of Learning Objectives on the ability to understand mathematical concepts in Trial I

\begin{tabular}{|c|c|c|c|}
\hline \multirow{2}{*}{ No } & \multirow{2}{*}{ Learning Objectives } & \multicolumn{2}{|c|}{$\begin{array}{c}\text { Ability to Understand Student } \\
\text { Mathematical Concepts }\end{array}$} \\
\hline & & $\begin{array}{l}\text { \% Achievement of } \\
\text { Learning Objectives }\end{array}$ & Information \\
\hline 1 & $\begin{array}{l}\text { Students give examples } \\
\text { and not examples of } \\
\text { cubes and blocks }\end{array}$ & $86,66 \%$ & Achieved \\
\hline 2 & $\begin{array}{l}\text { Able to present cube and } \\
\text { beam concepts in the } \\
\text { form of mathematical } \\
\text { representations }\end{array}$ & $78,66 \%$ & Achieved \\
\hline 3 & $\begin{array}{l}\text { Students are able to } \\
\text { restate the concept of } \\
\text { cubes and blocks into } \\
\text { problem solving }\end{array}$ & $78,66 \%$ & Achieved \\
\hline 4 & $\begin{array}{l}\text { Apply the concept of } \\
\text { cubes and blocks into } \\
\text { problem solving }\end{array}$ & $66,66 \%$ & $\begin{array}{l}\text { Not yet } \\
\text { achieved }\end{array}$ \\
\hline 5 & $\begin{array}{l}\text { Able to calculate the } \\
\text { surface area and volume } \\
\text { of cubes and beams }\end{array}$ & $62,66 \%$ & $\begin{array}{l}\text { Not yet } \\
\text { achieved }\end{array}$ \\
\hline
\end{tabular}

From the table above shows that not all items have reached the criteria of achievement of learning objectives, only 3 items, namely questions number 1,2 and questions number 3 of 5 items that reach the criteria of achieving learning objectives of at least $75 \%$. Thus the achievement of the learning objectives in the first trial for the results of the Posstest the ability to understand students' mathematical concepts has not been achieved.

\section{c. Results of Student Response Questionnaire on Trial I}

The average percentage of the total positive response of students in the first trial was $95.42 \%$. If the results of this analysis are referred to the criteria set out in chapter III, it can be concluded that the students' responses to the components and learning activities are positive, because, more than $80 \%$ of students give a positive response to the components of instructional materials developed.

\subsection{Trial Results II}

In the field trial II, it was conducted to measure the practicality and effectiveness of teaching materials (draft
III) which was developed based on a realistic mathematical approach that aimed to improve the ability to understand students' mathematical concepts. The following is a description of the results in trial II.

\subsubsection{Effectiveness Description of Teaching Materials in Trial II}

\section{a. Classical Student Learning Completeness Trial II}

Description of the percentage of classical completeness criteria the ability to understand students' mathematical concepts in trial II is presented in the following Figure 5:

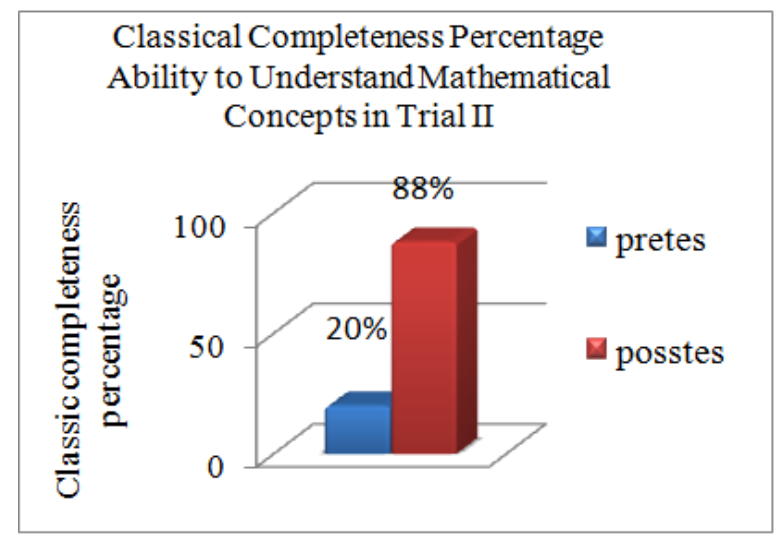

Figure 5. Percentage of Classical Completeness Ability to Understand Students' Mathematical Concepts in Trial II

The classical completeness of the results of students' ability to understand mathematical concepts at pretest II trial was $20 \%$ while in the posttest II trial was $88 \%$. In accordance with the criteria of classical student learning completeness, which is a minimum of $85 \%$ of students who take learning can achieve a score of $\geq 70$, then the posttest results of the ability to understand mathematical concepts in trial II have met the criteria for achieving classical completeness because it obtained $88 \%$ completeness. So it can be concluded that in the second trial the application of instructional materials based on the developed metacognition approach has met the criteria for achieving classical mastery learning outcomes.

If categorized based on the level of mastery of students, then the level of mastery of the ability to understand students' mathematical concepts on the results of pretest and posttest trial II can be seen in Figure 6 below:

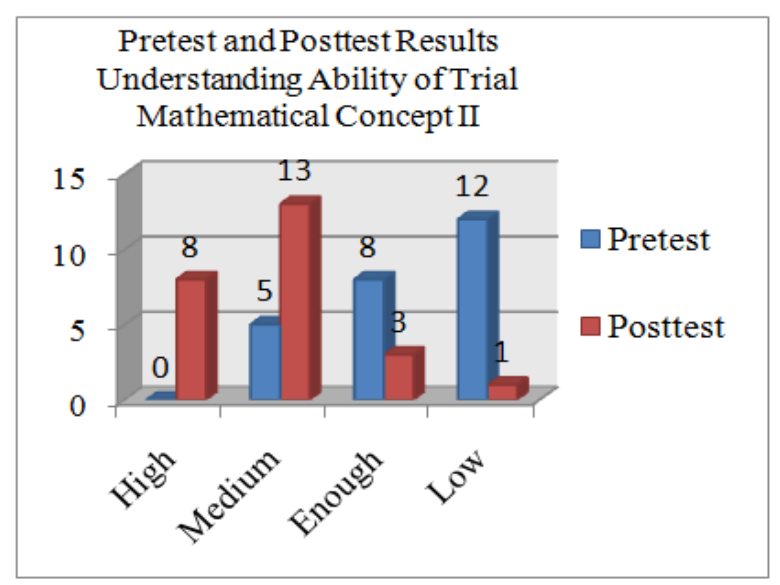

Figure 6. Percentage of Pretest Value and Posttest Understanding of Mathematical Concept Ability in Trial I 
Data obtained from the results of the pretest and posttest ability to understand the mathematical concepts of students in the trial II, were analyzed to determine the increased ability to understand students' mathematical concepts. The improvement is seen by calculating the n-Gain value based on the results of the pretest and posttest in the trial II.

The results of N-Gain students if viewed based on the average pretest and posttest scores the ability to understand mathematical concepts also increased. The average pretest and posttest in trial II were 57.86 and 78.4, respectively, which resulted in a difference in the pretest and posttest scores of 20.54. Based on the results of the N-Gain calculation, it was found that the ability to understand students' mathematical concepts in the first trial was 0.49 or categorized as "Medium".

\section{b. Achievement of Trial Learning Objectives II}

The results of the students' understanding of mathematical concepts in the first trial showed that the achievement of learning objectives in problem number 1 was $85.33 \%$, the achievement of learning objectives in question number 2 was $78.66 \%$, the achievement of learning problem number 3 was $86.67 \%$ achievement. The learning objective of question number 4 was obtained at $76 \%$ of the achievement of the learning objective of question number 5 was obtained at $77.33 \%$. There are several factors that influence the trial II, including the learning process and the learning that is carried out by students, in the second trial there are some improvements in student books, this is done because in the trial I many students not understand in some discussions.

In accordance with the criteria for the achievement of learning objectives, it is said that the learning objectives are achieved with a criteria of $75 \%$ of the maximum score of each item, thus the achievement of learning objectives in the trial I for the results of the Posstest ability to understand students' mathematical concepts have been achieved.

\section{c. Student Response in Trial II}

The average percentage of the total positive response of students in the second trial was $96.06 \%$. If the results of this analysis are referred to the criteria set out in Chapter III, it can be concluded that the students' responses to the components and learning activities are positive, because, more than $80 \%$ of students give a positive response to the components of instructional materials developed.

\subsection{Discussion of Research Results}

\subsubsection{Development of Teaching Materials Based on Valid, Practical, and Effective Metacognition Approaches}

The teaching materials developed in this study are teaching materials based on metacognition approaches. In general, the purpose of this study is to produce a product in the form of teaching materials that can improve the ability to understand mathematical concepts of junior high school students. Hudojo [22] states that learning mathematics requires an understanding of concepts. These concepts will give birth to theorems or formulas.

In order for concepts and theorems to be applied to other situations, it is necessary to use the skills and concepts and theorems. Therefore, mathematics learning must be emphasized towards understanding concepts. In line with the results of the researches by Wasriono, Syahputra, and Edy Surya [23] it was shown that this learning device with an assisted assisted discovery model was valid, practical, and effective.

Metacognition is one approach that is related to the ability to understand mathematical concepts. One characteristic of learning and research on developing learning is emphasizing methods to make students more aware and responsible for their own knowledge and thinking. According to Purnomo [24] Metacognition knowledge is divided into three sub-types, namely: (1) strategic knowledge; (2) knowledge of cognitive tasks that include contextual and conditional knowledge; and (3) selfknowledge. Through the metacognition questions given by students and directed trained to get used to and beable to realize his own thought process in understanding concepts.

The ability to understand concepts mastered by students is better if accompanied by application. Effandi [25] stated "the stage of understanding an abstract mathematical concept will be enhanced by realizing the concept in the practice of teaching". Furthermore Vygotsky (in abidin) [26] believes that "intellectuals develop when they try to overcome the discrepancies generated by these experiences.

Based on the initial findings of researchers in the field related to the research subject, the ability to understand students' mathematical concepts as a whole has not been completed in a classical manner. This is because the teacher does not have good and appropriate teaching materials to improve students' ability to understand concepts. Haggarty and Keynes (in unal) [27] state that "in order to improve the teaching and learning of mathematics in the classroom it is necessary to work to improve the understanding of teachers, students, materials used for learning and interaction between them". For that reason, in this study, it is necessary to develop teaching materials that are in accordance with the needs of students, as well as be able to direct and familiarize students to cognize in understanding concepts by applying metacognition approaches.

The development of teaching materials based on the metacognition approach in this study was carried out in accordance with the 4-D development model procedure. The 4-D development model consists of four systematic stages and is always revised before testing to produce a good product. The teaching material developed must be of good quality. The quality of good teaching materials must meet valid, practical and effective criteria.

Based on the results of trials of teaching materials carried out in class VIII-A at the first trial phase, information and research findings were found to be the basis for improving teaching materials. This is because in the first trial phase, the learning implementation has not reached the specified criteria so that it does not meet the effective criteria. After the revised trial, the research continued to II. The result is teaching materials based on metacognition approach developed meet the criteria of valid, practical, and effective. Level of validity in terms of content and construct validity. Practicality in terms of the evaluation of the validators, the response of teachers and students as users of teaching materials and the implementation of teaching materials, while effectiveness 
is seen from the completeness of students 'classical learning outcomes, the achievement of student learning outcomes, and students' positive response.

\subsubsection{Improving the Ability of Understanding the Concept by Using Teaching Materials Based on the Metacognition Approach}

Concept understanding is the main basis in mathematics learning. One of the objectives of mathematics in secondary education listed in the Minister of National Education Regulation No. 22 of 2006 concerning Content Standards is having the ability to understand mathematical concepts. Furthermore Hudojo [28] stated that "learning mathematics requires an understanding of concepts, these concepts will give birth to theorems or formulas". From the description, it can be understood that the ability to understand concepts mathematics wants students to be able to use or apply what they have understood into learning activities. If students have a good understanding, then the student is ready to give definitive answers to questions or problems in learning.

When students understand and can express mathematical ideas, their understanding is deeper and longer intact, they can present these mathematical ideas both in mathematical models, in pictures, diagrams, tables, and into words they understand, and for their own interests and experiences. This is in line with the results of Afiani's research [29] which states that in order to improve student learning achievement teachers need to pay attention to factors that influence student achievement, both internal and external factors. Other research on the ability to understand concepts undertaken by Hasibuan, Surya, and Syahputra [30] conclude "The implementation of contextual approach with mathflash graphic media can improve students' mathematical concept aunderstanding ability in addition and subtraction integer operation in VII Junior High School.”

The teaching materials developed in this study have met the criteria for valid, practical, and effective. Based on the results of the pretest and posttest analysis of the ability to understand students' mathematical concepts in trial I and trial II shows that the ability to understand mathematical concepts of students increases. The improvement of the ability to understand mathematical concepts is seen by the $\mathrm{N}-$ Gain calculation of students in each trial, where in the first trial when the effectiveness criteria were not fully fulfilled. There was an increase in the ability to understand the mathematical concepts of students in the low category. Whereas in the second trial after the effectiveness criteria were met, there was an increase in the ability to understand the mathematical concepts of students in the medium category. Improved ability to understand mathematical concepts better occurred in trial II, this is because improvements in the quality of teaching materials based on weaknesses were found in test I. These results indicate that the use of teaching materials based on the metacognition approach developed has an impact on improving comprehension skills students' mathematical concepts. This is reinforced by the results of another study by Fauzi [31] who found that "with the application of the metacognition approach and equipping students to establish mathematical connections of students, the results of the research showed that there were differences in the average mathematical connection abilities of the three learning groups; (PPMG, PPMK, and PB) and each are increased. According to Piaget's development theory (in Trianto) [32] namely looking at cognitive development as a process in which children actively build systems of meaning and understanding reality through their experiences.

From the Piaget theory, it can be concluded that the Piaget theory is related to understanding. In this case, the experiences and interactions of children with the environment affect the child's understanding ability. The more experiences children have with the environment, the easier it is for children to develop their knowledge with the environment. The ability to understand mathematical concepts can be increased due to the teaching materials applied to students have met the criteria for the quality of good teaching materials, with the good teaching materials used and with the application of the metacognition approach, the ability of students' mathematical understanding increases. Therefore, in this study it can be concluded that teaching materials based on the metacognition approach developed can improve students' understanding of mathematical concepts.

\section{Conclusion}

Based on the results of the analysis and discussion in this study, several conclusions were presented as follows:

1. Teaching materials based on metacognition approaches that are developed valid, practical and effective are used to increase the ability to understand mathematical concepts and learning independence of students of Budi Mulia Medan Middle School.

2. Increased ability to understand students 'mathematical concepts using teaching materials based on metacognition approaches on cube and beam material increased from trial I to trial II, seen from the average achievement of students' conceptual comprehension abilities in the first trial of $68.33 \%$ increasing to $73.33 \%$ in trial II.

3. Student learning independence increases from trial I to trial II using teaching materials based on metacognition approaches.

\section{Suggestions}

Based on the results of the research and the conclusions above, several things can be suggested as follows:

1. On the test of the ability to understand the mathematical concepts the teacher is advised to pay more attention to determining alternative solutions so that students are accustomed to working on the problem of understanding concepts.

2. Motivating yourself in indicators of learning independence needs to be improved by being more confident in yourself and not just relying on others.

3. The researcher recommends that the teacher and the reader so that the instructional materials that have been developed are expected to be continued at the disseminate stage of the teaching material, so that it can be considered for teaching materials used in schools on a broader scale. 


\section{References}

[1] Hadijah, S., Hasratudin., dan Napitupulu, E. (2016). Effect of Jigsaw Cooperative Learning on Students' Understanding Ability and Mathematical Communication Skills. JURNAL TABULARASA PPS UNIMED. Vol.13 No.3, Desember 2016: 285-299

[2] Walle, V.D. 2008. Development of Volume Sixth Elementary and Secondary School Mathematics Teaching 1. Jakarta: Erlangga.

[3] Gagne, Dimyati \& Mujiono (2006:10), Learning and Learning, Jakarta : Rineka Cipta.

[4] Hasibuan, A. Z. O, Surya. E Syahputra. E (2017) The Application Of CTL To Improve Student's Understanding Concept Ability By Matflash Graphic Media Assistance Ijariie Vol-3 Isuue-2 2017. Issn(O) 2395-4396.

[5] Kesumawati, N. 2008. Understanding Mathematical Concepts in Mathematics Learning. National Mathematics and Mathematics Education.

[6] Sulistyaningsih, D. \& Mawarsari, V.D. 2015. Effectiveness of Construscivism-Based Team Assisted Individualization Cooperative Learning Models to Improve Creative Thinking Ability. JKPM, Volume 2 No 1, April 2015.

[7] Ahmadi, I.K, dkk. (2011). Integrated School Learning Strategy. Jakarta:Prestasi Pusaka

[8] Kusumam, A, dkk. 2016. Development of Basic Subject Teaching Materials and Electrical Measurements for Vocational High Schools. Journal of Technology Education and Kejuruan, Vol 23, No 1. Hal. 28-29.

[9] Fannie, R.D dan Rohati. 2014. Development of POE (Predict, Observe, Explain) Student Worksheets in the Linear Program Class XII High School Materials. Sainmatika journal.Vol 8 No 1: 96-109

[10] Ramdani, Y. (2012). Development of Instrument and Teaching Materials to Improve Understanding of Concepts, Reasoning and Mathematical Connections in Integral Concepts.FMIPA Unisba. Educational Research Journal. Vol 13. No. 1:44-52.

[11] Lasmiyati \& Idris, H. (2014). Development of Learning Modules to Improve Understanding of Concepts and Interest in Middle School. Journal of Mathematics Education Volume 9 - Number 2, December 2014, (161-174).

[12] Handayani, L.S., dkk. (2014). Effect of Think Aloud Pair Problem Solving Method (TAPPS) on the ability to understand High School Students' Mathematical concepts. Journal of Mathematics Education.

[13] Widianingsih, A. \& Wulan, R.A. 2015. The Effect of Metacognition Strategies Toward Mastery of Concepts and Scientific Attitude of Students Class XI in Learning Mathematics. Seminar Nasional XII Pendidikan Matematika FKIP UNS 2015

[14] Rukminingrum, D.V., Hanurawan, F., \& Mudiono, A. (2017) Learning Metacognitive Learning of Class V Elementary School Students. Journal of Education: Theory, Research and Development Vol 2 No 2 EISSN: 2502-471X : 280-284.
[15] Yamin, M .2013. Strategies and Methods in the Learning Innovation Model. Jakarta: Gaung Persada Press group.

[16] Mawaddah, NE., Kartono., \& Suyitno, H. 2015. Learning Model of Discovery Learning with Metacognitive Approach to Increase Metacognition and Mathematical Creative Thinking Ability.Unnes Journal of Mathematics Education Research. ISSN 2252-6: 1-11.

[17] Widianingsih, A. \& Wulan, R.A. 2015. The Effect of Metacognition Strategies Toward Mastery of Concepts and Scientific Attitude of Students Class XI in Learning Mathematics. Seminar Nasional XII Pendidikan Matematika FKIP UNS 2015

[18] Sugiyono. 2006. Qualitative and Quantitative Research Methods R\&D. Bandung: Alfabeta.

[19] Arikunto, S. 2009. Research Procedure (A Practice Approach). Yogyakarta: PT. Rineka Cipta.

[20] Nieveen. 2007. An Introduction to Educational Design Research. Enschede. Netzodruk.

[21] Hake, R.R. 1999. Analizying Change/Gain Scores. Tersedia online di http://physics.indiana.edu.

[22] Herman Hudojo. Curriculum Development and Mathematics Learning. (Malang: Universitas Negeri Malang, 2005). h.123

[23] Wasriono, Syahputra, E \& Surya, E. Development of Autograph Assisted Learning Devices to Improve Understanding of Students' Mathematical Concepts through Guided Discovery Models. Paradikma Journal,Vol. 8, Nomor 3, Desember 2015, hal 52-61.

[24] Dwi Purnomo, 2013. Class VII Students' Mathematical Metacognition Action in Building Understanding of the Concept of Two-Dimensional Linear Persammation Systems. Malang: IKIP Budi Utomo Malang.

[25] Effandi Zakaria, dkk, Mathematics Teaching and Learning Trends, Kuala Lumpur: Publication Envoy and SDN BHD Distributor, hlm. 86.

[26] Abidin, Y. (2014). Learning System Design in the Context of 2013 Curriculum. Bandung:Refika aditama.

[27] Unal, H. 2006. Preservice Secondary Mathematics Teacher's Comparative Analyses of Turkish and American High School Geometry Textbook. Kastamonu Education Journal. 14/2: 509-516.

[28] Herman Hudojo. Curriculum Development and Mathematics Learning. (Malang: Universitas Negeri Malang, 2005). h.123

[29] Afiani Nur. 2017. The Influence of Mathematical Communication Ability and Independence of Learning Against Mathematics Learning Achievement. Study Journal of Mathematics Education (JKPM). 2(1), 1-13

[30] Hasibuan, A. Z. O, Surya. E Syahputra. E (2017) The Application Of CTL To Improve Student's Understanding Concept Ability By Matflash Graphic Media Assistance Ijariie Vol-3 Isuue-2 2017. Issn(O) 2395-4396.

[31] Fauzi, M.A. 2013. Students' Mathematical Connections Ability with Metacognitive Learning Approaches in Junior High Schools. Educational Journal of Matemtaika Paradikma. Vol. 6. No I.

[32] Trianto. 2009. Designing Innovative-Progressive Learning Models: Concepts, Platforms and Their Implementation in Education Unit Level Curriculum (KTSP). Jakarta: Kencana Prenada Media Group. 